\title{
Radioallergosorbent Test
}

National Cancer Institute

\section{Source}

National Cancer Institute. Radioallergosorbent Test. NCI Thesaurus. Code C78179.

A type of blood test used to test for allergies. 